\title{
Antonio Gramsci
}

Various important dates will be commemorated in 2017: the 80th anniversary of the death of Antonio Gramsci, the 100th anniversary of the Russian Revolution, the 50th anniversary of the assassination of Che Guevara and the 20th anniversary of the death of Paulo Freire. Considering this historic legacy, this issue of the prestigious Revista Katálysis presents content that confronts the "state of exception" that has been imposed on Brazil to once again bury the struggles to advance in the democratization and socialization of economic, political and cultural power. In fact, at the same time that they are inspired by the extraordinary thinking of the popular debates of the twentieth century, the authors of the articles in these pages do not lose sight of the incendiary contemporary problems, particularly the crisis that has shaken Brazil in recent years.

As the results of studies by a considerable group of scholars, the reflections proposed here could not be more current and opportune, in one of the most crucial periods of Brazilian history, which perhaps presents the greatest test yet for our young and mutilated democracy. For this reason, the analyses of democracy and the concern for its future are clearly visible in various articles and in the background of others. Fernando Gaudereto Lamas and Ednéia Alves de Oliveira properly locate the issue of democracy today within the current metabolic social order of capital and the intensified class struggle. They show that the notion of democracy has become mere rhetorical discourse and bourgeois phraseology. It is being held hostage to a capitalism that is increasingly devastating and concentrated, and that manipulates political institutions and the collective imaginary to assure its hegemony and weaken any attempt to construct popular sovereignty. Using theoretical references from Gramsci and debates about democracy, Emilie Faedo Della Giustina and Danuta Estrufika Cantóia Luiz sketch a complex and critical framework of the Brazilian context, tracing the period since the redemocratization of Brazil until the mass demonstrations of 2013.

In somber times such as these, Douglas Ribeiro Barboza and Jacqueline Aline Botelho Lima Barboza could not be more pertinent in their article Sociedade regulada e do radicalismo democrático [Regulated Society and Democratic Radicalism]. They reconstruct the theoretical field of Marxism established by Gramsci and show that the route towards resolving the grave crisis affecting Brazil and the world is the creation of a (self)-regulated society where the division between governments and the governed is overcome by the protagonism and political organization of the subaltern classes. In the same direction, the political radicality of the concepts of liberation, interdisciplinary conception, and political-pedagogical practice of the oppressed which even includes critical environmental education - is revived by César Augusto Costa and Carlos Frederico Loureiro in an article about Paulo Freire, the indispensable educator of the "viable unprecedented" and of the routes to a revolutionary pedagogy.

Connected to the theme of democracy, issues arise related to the function of intellectuals, culture, racism, homophobia and the countless molecular battles in which the disappropriated classes are engaged in their daily history to conquer rights and win recognition of their multiple social and political subjectivities. In this sense, by reconstructing Gramsci's political analysis about the function of intellectuals, culture and the subaltern classes in Italy, Daniela Xavier Haj Mussi raises the crucial and current question of the performance of organic intellectuals in the resistance against the project of counter-reform underway in Brazil. A similar sensibility is found in the article, Trabalho socioeducativo no Serviço Social à luz de Gramsci: o intelectual orgânico, [Gramsci and Socio-educational Work in Social Service: the organic intellectual] by Adriana Giaqueto Jacinto, which reveals the contribution of Gramscian thinking to the analysis of relations between culture and politics in the educational praxis of social assistants in popular Brazilian reality. In keeping with these issues, the bold article Contribuições gramscianas sobre raça, identidade cultural e velhice na perspectiva de Stuart Hall, [Gramscian Contributions about Race, Cultural Identity and Aging in the Perspective of Stuart 
Hall], by Elaine Lima da Silva and Juceli Aparecida da Silva, opens a field of reflection about phenomenon that are increasingly widespread in Brazil. Addressing another theme that is little studied in the realm of Marxism, Serviço Social e homofobia: a construção de um debate desafiador, [Social Service and Homophobia: the construction of a challenging debate], Moisés Santos Menezes and Joilson Pereira Silva, present the view of various authors about the prejudice that permeates Brazilian culture. They portray how social service faces the issues of sexual diversity and gender and the demands raised daily by the LGBT population, looking at the various contradictions that this issue has raised for the category.

As a journal linked to social service, there is no lack of experiences and issues encountered by the professionals of this specialty who face difficult situations in Brazil's complex and contradictory social reality. It is in the realm of this living and combative context that there has been a considerable production of articles related to Gramsci's thinking. One of these portraits is offered by the study of Ivete Simionatto and Fabiana Negri, Gramsci e a produção do conhecimento no Serviço Social brasileiro [Gramsci and the Production of Knowledge in Brazilian Social Service]. Focused on the period from 2000 to 2015, Siminionatto analyzes the production of knowledge of social service based on Gramscian thinking, revealing the most recurrent themes and the formation of a critical and militant professional culture. In the same way, in the article Serviço Social e tendências teóricas atuais, [Social Service and Current Theoretical Trends] by José Fernando Siqueira da Silva, we find contributions to the debate about current theoretical-methodological tends in Brazilian social service, referenced in Marxist social theory and highlighting two important Gramscian categories: intellectuals and cultural direction. In her article Apontamentos sobre Gramsci e sua influência ao Serviço Social no século 21, [Considerations on Gramsci's Influence in 21st Century Social Service], Angela Vieira Neves highlights Gramsci's importance to social service in Brazil by bringing to light the dispute between conservative political culture and a concept built on the influence of Marxist tradition. Finally, Josimeire de Omena Leite and Ana Cristina Brito Arcoverde, in Hegemonia e filosofia da práxis: os desafios ao Serviço Social, [Hegemony and Philosophy of Praxis: Challenges to Social Service], use Gramsci's concepts of the philosophy of praxis, hegemony and the organic intellectual to analyze new challenges presented to social service professionals by the conservative restoration and the manipulations of post-modern thought.

In times of deep crisis - not only economic, but also political, social and cultural -which require more intense, critical and collective reflection about the current direction of the world, in which an accumulation of energy and extraordinary organizational capacity are needed to overcome the decayed and destructive bourgeois society, Revista Katálysis serves as a trench and fortress for confronting the chaotic and explosive situations that are aggravating Brazil. It also does not become discouraged in the light of struggles for a society founded on self-government of the associated producers. The new and more devastating wave of neoliberalism that strikes the world and destabilizes our country, in addition to deepening inequalities and levels of poverty, has resolved to shatter democracy, even in its liberal and social democratic forms. Nevertheless, paradoxically, if the class antagonism that is clearly intensifying becomes well organized, new revolutionary perspectives can be revealed, reviving the most authentic and radical meaning of democracy conferred by Gramsci. The Sardinian intellectual portrays democracy as the collective political process that can transport the subaltern classes from a position of the led to the condition of leaders in an unprecedented and higher conception of society.

Giovanni Semeraro, March 2017.

\section{Giovanni Semeraro}

Gsemeraro07@gmail.com

Doctor in Education from the Federal University at Rio de Janeiro (UFRJ)

Professor of the Philosophy of Education at the Federal Fluminense (UFF)

\section{UFF}

Rua Professor Marcos Waldemar de Freitas Reis, São domingos

Niterói - Rio de Janeiro - Brazil

CEP: 24210-201 